\title{
The Role of Managerial Competencies in Foreign Direct Investments
}

DOI 10.18267/pr.2021.krn.4816.15

\author{
Anna Para \\ ORCID iD: 0000-0002-2371-7069 \\ apara@sgh.waw.pl \\ Warsaw School of Economics, Department of International Management \\ Warsaw, Poland
}

\begin{abstract}
Foreign direct investments (FDIs) are perceived to be the most advanced internationalization form. FDIs bring benefits not only to the country's economy but most importantly to the companies that make investments abroad. In case of Poland, the incoming FDI flow significantly outnumbers the Polish outward FDIs. One of the greatest barriers for Polish companies to invest abroad are lack or insufficient financials as well as investment risk aversion. Another crucial factor that can deter organizations from FDIs might be insufficient managerial competencies. The aim of the study is to verify if the managerial competencies are important for deciding and conducting FDIs as well as to determine what are the most crucial managerial competencies required in this process. The author conducted the literature review as well as in-depth interviews with managers, who participated in the process of foreign direct investments made by Polish companies in the period of 2010-2020. The results od the study confirm that there is imbalance between demand and supply for qualified managers. There are more Polish companies willing to invest abroad but they struggle to find competent managers as the knowledge, skills and experience related to the FDIs are very scarce. Respondents find international experience, industry knowledge, openness as well as cultural management skill as the most important managerial competencies in context of internationalization through FDI. The results of the study advance the knowledge in the field of international management. As far as the author is aware, previous works have not comprehensively considered the importance of managerial competencies in FDIs.
\end{abstract}

Keywords: FDI, foreign direct investment, competency-based management, internationalization.

JEL Classification codes: F21, M21

\section{INTRODUCTION}

Foreign direct investments (FDI) are perceived to be the most advanced way of internationalization. FDIs bring benefits not only for investing company but also for the economy of both countries involved. Among the benefits are e.g., the creation of the new workplaces, human capital development, the exchange of know-how and expertise, access to the new resources.

Despite the growing dynamics of international activity of Polish companies, Poland is still one of the largest recipients of FDI inflows in Central Europe. Every year about 300 investment projects is located in Poland. At the same time Polish companies conduct around 30 investments investment projects abroad (Crido, 2020). Although the fact that Polish organizations are very focused and successful in exporting goods and services, FDIs seem to be disregarded way of internationalization. 
Although the fact that Poland is a market economy for 30 years and a member of European Union since 2004, the number and value of outward FDI can be perceived as low. According to UNCTAD's data (UNCTAD, 2020), FDI inflows to Poland remained stable in 2019, reaching PLN 52 billion (USD 13 billion). On the other hand, in 2019, the value of Polish outward direct investment transactions amounted to PLN 5,0 billion (USD 1,3 billion). In 2019, a relatively high value of transactions due to Polish outward direct investment was recorded in Czech Republic - PLN 11.4 bn and in Germany - PLN 5.8 bn (NBP, 2020). Because of the cultural and geographical proximity the Polish outward FDIs are located mostly in Europe.

There are several barriers for Polish companies to invest abroad. Firstly, it is the insufficient financial liquidity, lack or insufficient number of financial resources. Secondly, it is the investment risk that deters Polish companies from FDIs. Lastly, those might be managerial competencies and competency gaps that lower the chances of success in internationalization, mainly in form of FDIs.

The aim of this research is to verify what is the role of managerial competencies in FDIs. Moreover, the secondary goal is to detect and to analyse the most important managerial competencies that play crucial role during conducting greenfield and brownfield investments.

\section{LITERATURE REVIEW}

\subsection{Polish Foreign Direct Investments}

Foreign direct investment is defined as an international transfer of capital in order to establish a branch in another country and exercise control over it (Krugman, Obstfield, 2012). FDI can be also described as an investment involving a long-term relationship and reflecting a lasting interest and control by a resident entity in one economy (foreign direct investor) in an enterprise resident in an economy other than that of the foreign direct investor (OECD, 2008). The main goal of the investment is to obtain lasting interest by an investor from one country in an enterprise located in another country. The lasting interest implies the existence of a longterm relationship between the direct investor and the direct investment enterprise and a significant degree of influence on the management of the latter. Lasting interest is established when an investor obtains at least $10 \%$ of the ordinary shares (votes) - both directly and indirectly.

There are two basic types of direct foreign investments - greenfield and brownfield investments. Greenfield investment happens when a company builds its own facility from scratch. With brownfield investment, a company acquires or merges with an existing company (Krugman, Obstfeld, 2012). Moreover, we can distinguish direct horizontal and vertical investments. Horizontal investments consist in duplicating the investor's basic production process elsewhere in the world, while the latter involve relocating only part of the production chain to another country (Weresa, 2002).

Different forms of investment require a different preparation of a business plan, and thus a mix of managerial competences. Another resource of knowledge and skills will be required to take over a foreign company and incorporate it into the structures of an already operating enterprise than in the case of building a branch or factory outside the home country.

Poland is perceived as an attractive location for doing business in Central and Eastern Europe. Many foreign investments are located in the country. For example, in 2018, as many as 272 investment projects were implemented in Poland. For comparison, in this period Hungary attracted 101 investments (EY, 2019). Foreign investors have located production plants, company branches and outsourcing centres in Poland, thus obtaining benefits such as access 
to qualified employees, the acquisition of well-known brands or sales and distribution channels. Similar opportunities and benefits can be achieved by Polish companies investing abroad.

Most of Polish FDIs are brownfield investment whereas greenfield are less common. Lug SA operating in the lighting industry is one example of a Polish company that decided to create its own factory abroad. In 2018, the company completed the construction of a factory in Argentina that has become a strategic expansion centre for the company in the South America region. As for the examples of companies that took over foreign companies recently, one can mention Elemental Holding, R22, Kross, Samasz. Elemental Holding has completed several foreign direct investments. In 2017, Elemental Holding took over the Lithuanian company UAB "EMP recycling". Then, in 2018, the company acquired $85 \%$ of the shares of the German company Recat. The purpose of this acquisition was to increase the scale of the group's operations on the market of recycling used car catalysts in Western Europe. In 2019, Elemental Holding invested in the United States, the company acquired $66 \%$ of the shares of the American company PGM of Texas LLC, which allowed to increase the development of the capital group on the largest catalyst recycling market. Another example is R22 Group operating in the technology industry. In 2018 the company acquired three Romanian firms operating in the area of hosting and domains. This step allowed R22 to gain a leadership position and get $25 \%$ share in the Romanian hosting and domain industry. A year later, in 2019, R22 took over the Croatian company Avalon. Thanks to this acquisition, R22 gained an approx. $30 \%$ share in the market and became the vice leader in the Croatian hosting and domain industry.

Every year, Polish enterprises make about 30 foreign investments, taking over foreign companies or creating their own production plants from scratch. At the end of 2019, the balance of receivables from Polish direct foreign investments amounted to PLN 96.5 billion and was higher by PLN 4.0 billion than in the previous year (NBP, 2020).

If we analyse the value of FDIs calculated as \% of GDP, it turns out that Poland is almost at the end of the list. According to OECD data, foreign direct investment, calculated as \% of GDP, amounted to $504,9 \%$ of GDP in Luxembourg, 309\% in Netherlands and $190 \%$ of GDP in Switzerland in 2019. The average for the European Union countries was $70.7 \%$, and the result for Poland was 4.4\% of GDP. The low level of Polish FDIs is primarily due to the relatively low competitiveness of Polish enterprises on the global market, as well as institutional conditions, which to a small extent stimulate international expansion of enterprises. On the other hand, Polish companies are still in the early stage of internationalization. It means that they will gradually overcome the psychological barriers and lack of knowledge and international experience. Therefore, it can be argued that managerial competences can play an important role in FDIs (Karaszewski et al. 2010).

\section{Fig. 1 FDI stocks outward as \% of GDP in 2019}

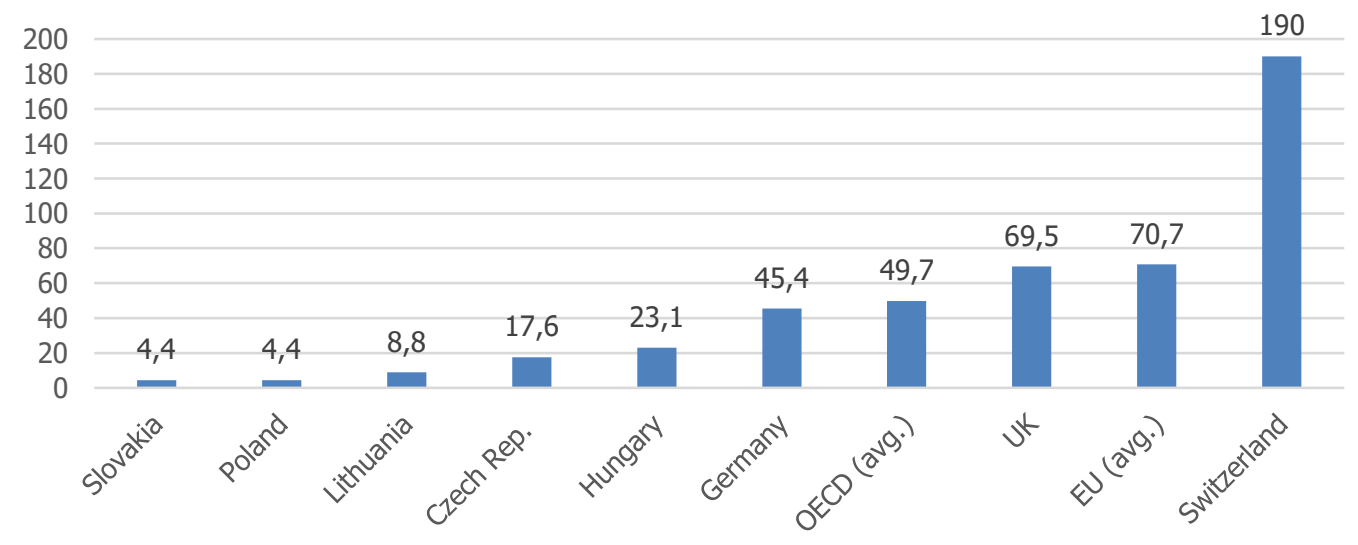

Source: OECD, 2020 
The vast majority of Polish FDIs in 2019 fell to European Union countries (78.2\%). This is mainly due to geographical and cultural proximity as well as political conditions, e.g. common, single EU market. The decision to locate Polish outward investments in European countries is mainly influenced by the knowledge of the specificity of running a business in these markets, knowledge of the language and culture. This regularity is also noticed among other investors from around the world. The first three places in terms of receivables from Polish FDI are Luxembourg, Cyprus and the Czech Republic, while Luxembourg's and Cyprus' high position is due to the fact that the frequent motivation for investing in this country is the optimization of structures and the use of regulatory arbitrage, i.e. the search for efficiency.

Tab. 1 Polish outward FDIs. Receivables by geographical region or country, 2019.

\begin{tabular}{|l|l|l|}
\hline Geographical region or country & mln EUR & $\%$ \\
\hline All countries & 22669,6 & $100 \%$ \\
\hline Europe & 20576,8 & $90,77 \%$ \\
\hline UE-28 & 17727,8 & $78,20 \%$ \\
\hline OECD & 14054,4 & $62,00 \%$ \\
\hline 1. Luxembourg & 4508,9 & $19,89 \%$ \\
\hline 2. Cyprus & 2873,6 & $12,68 \%$ \\
\hline 3. Czech Republic & 2672,5 & $11,79 \%$ \\
\hline 4. Germany & 2364,2 & $10,43 \%$ \\
\hline 5. Hungary & 1334,1 & $5,88 \%$ \\
\hline 6. Netherlands & 1301,1 & $5,74 \%$ \\
\hline 7. Lithuania & 1103,4 & $4,87 \%$ \\
\hline 8. United Kingdom & 1013,7 & $4,47 \%$ \\
\hline 9. Romania & 887,3 & $3,91 \%$ \\
\hline 10. Russia & 732,7 & $3,23 \%$ \\
\hline
\end{tabular}

Source: NBP, 2020

The results of the research conducted by the Polish Economic Institute indicate that the tendency to locate Polish FDIs primarily in Europe will not change in the coming years. According to the declared investment plans, also in the years 2020-2021 most investments will be located in the European Union, most often in Germany and the Czech Republic (Polski Instytut Ekonomiczny, 2019).

\subsection{The role of managerial competencies in international expansion}

Foreign direct investment is considered to be the most advanced form of enterprise expansion. According to the Uppsala model of internationalization, this process runs in phases, sequences. The stage of irregular exports is followed by the stage of occasional exports, then exports through independent intermediaries. The next steps are the creation of a sales department and the creation of a branch (production department) (Johanson, Wiedersheim, 1975). The authors of this model pointed out in 1975 that the limitations of the internationalization process are primarily: lack of knowledge about foreign markets, lack of resources necessary for expansion, risk related to entering a foreign market, psychological distance between the home 
market and the expansion market, most often correlated with geographical distance, transport costs, tariff and non-tariff barriers.

FDIs require good preparation and is also associated with many challenges. The effectiveness of activities undertaken abroad depends, inter alia, on the quality of human capital and on the competencies of the team of senior managers. In the literature one can find a few studies and research on the importance of managerial competencies in making FDIs or on the impact of competences on the results achieved outside the company's home country.

The general list of managerial competences was developed by an American psychologist S. Motowidło. He listed ten skills that correspond to the tasks performed by management. The list includes leadership, teamwork, determination, negotiation skills, organizing, creativity, motivation, stress resistance, written and verbal communication (Pająk, 2003, p. 148-150). Other managerial competences described in the literature are technical, social, conceptual skills, interpersonal and diagnostic skills, communication skills, decision-making skills, and time management skills. In turn, the American researcher D. Goleman divided managerial skills into three categories. The first - purely technical skills such as accounting or business planning. The second - cognitive skills, such as analytical thinking. The third - skills that reflect emotional intelligence, such as good interaction with others and make changes efficiently (Griffin, 2007, p. 20-26).

The question arises, which of the general managerial competences will influence the propensity and ability to make decisions and the effectiveness of the process of conducting FDI? Research conducted in India on a sample of domestic production companies shows that managerial competencies influence the decisions regarding foreign capital expansion. Empirical studies have shown that previous experience of managers in international business is conducive to taking up FDI by organizations (Boermans, Roelfsema, 2013).

Researchers M.O Latukha and A. Y. Panibratov conducted research aimed at showing how managerial competencies affect the implementation of plans for foreign expansion. The survey was conducted among Russian companies operating in foreign markets. The results of the survey show that there is a strong correlation between the competences of the management and the effective implementation of the development strategy on foreign markets (also in the form of FDI). According to the researchers, the most important managerial competences are analytical skills, cognitive skills, the ability to create and use international contacts, project management skills, and the ability to establish intercultural relations (Latukha, Panibratov, 2015).

Moreover, the attitude of managers should be characterized by flexibility, adaptability and orientation towards quick learning. The competency profile of a global manager should also take into account sensitivity to cultural needs, the ability to adapt or acculturate, the ability to learn, entrepreneurship, and communication skills, especially intercultural communication (Pocztowski, 2002).

\section{METHODOLOGY}

To answer the research question the author conducted the literature review on FDIs and internationalisation searching for information about FDI barriers and role of managerial competencies in FDI. The second phase of the research was an empirical study that was conducted in form of in-depth interviews. The respondents target group were managers, who participated in the process of foreign direct investments made by Polish companies in the period of 2010-2020. The initial plan was to conduct 20 in-depth interviews with Polish managers, what turned out to be impossible because of the spread of Covid-19 pandemic. During the market turmoil, the majority of managers did not agree to participate in the 
research. Although the fact, that the interview was conducted remotely the most common reason was lack of time or no answear to repeated contact attempts. The purposive sampling technique was used in order to reach to knowledgeable experts. Firstly, the list of Polish companies that invested abroad in 2010-2020 was prepared in order to figure out the list of managers who participated in the process. The potential respondents were contacted via message on Linkedin platform, with use of Sales Navigator tool. The research sample consisted of 5 in-depth interviews. The interviews were conducted remotely in September and October 2020 with use of phone calls and internet communication platform Ms Teams. The interviews were recorded and analysed in order to search for patterns and common themes.

\section{RESULTS AND DISCUSSION}

When asked about the current state of Polish outward FDIs, the respondents emphasized that Polish companies still opt for less complicated forms of expansion, such as exports or joint ventures. One respondent noted that Polish companies are comfortable with operating in a very large internal market that provides access to a broad consumer base. The interviewee indicated that it is also a kind of limitation, as companies are not determined to look for their opportunities also outside Poland. He compared the motivation of companies from countries with small internal markets (such as Switzerland, Belgium, Austria), which must ensure an appropriate scale of operation and therefore also decide to invest abroad.

Polish companies usually focus mainly on export activities, considering it as a safe and beneficial form of expansion. There are numerous Polish companies that export as much as $80-90 \%$ of the production and do not intend to move on to the next stages of internationalization. Meanwhile, export advantages are usually based on geographical proximity, low logistics costs and low labour costs. Therefore, they are not permanent advantages.

The respondents underlined that Polish companies have gained only 30 years of experience in functioning on the market economy and that Polish firms have been active for 16 years on the EU Common Market. Undoubtedly, the EU accession in 2004 made Polish companies more internationally active.

One of the interviewees admitted that he had analysed the stages of his 30-year organization's internationalization process that took place in successive stages. From visiting foreign markets, learning about the trends and needs of consumers, as well as recognizing the law, through exhibiting at domestic and international fairs, first export successes, to joint ventures with foreign partners, and finally acquisitions of foreign companies. The respondent emphasized that the increasing involvement in international activities resulted in the development of the competences of the organization, as well as the knowledge and skills of employees and managers. Each subsequent step and more intense cooperation in the international arena deepened the knowledge about the specificity of individual markets and provided know-how related to internationalization. The interlocutor pointed out that without this experience he would not have been able to effectively manage the internationalization of the company.

All respondents admitted that lack or insufficient managerial competencies influence the international activity of Polish companies and might push or deter the firm from internationalization, especially in the form of FDI. The respondents stated that in Poland there are not many experienced managers, who participated in the process of investing abroad. Meanwhile, there are more and more companies interested or eager to invest abroad but they struggle to find experienced managers who could manage the investment process. It means that the demand for skilled managers exceeds the supply. 
Respondents stated that some competencies are especially important in the internationalization process in form of FDI. They listed knowledge in finance, business management, sales, legal issues as well as knowledge in the specific industry. Among the most crucial skills they listed international and intercultural management skills, leadership skills, market research and analysis as well as product or services analysis skills. In the opinion of respondents, the following attitudes are essential: openness towards other people, flexibility, and the willingness to cooperate. The respondents admitted that this is not a typical textbook knowledge. Usually, knowledge is acquired with experience and through cooperation with diplomatic missions, chambers of commerce.

The interviewees also paid a lot of attention to the skills of international and intercultural management. The respondents indicated the importance of understanding and the ability to navigate in a culturally diverse environment. On the one hand, they spoke of a kind of experience in the international world. The lack of these competences usually translates into communication errors and a lack of mutual understanding or incorrect reading of the messages of a foreign business partner. The respondents emphasized that cultural differences should be considered broadly, not only as different customs or gestures, but above all as differences at the level of deeply rooted beliefs and value systems. The awareness of cultural diversity and the ability to adapt to different realities in a given country were considered to be very important skills. In addition to cultural differences affecting communication, the respondents mentioned that there are also still competency gaps in communication in foreign languages. According to the respondents, the scale of this phenomenon is smaller and smaller each year, but it still exists.

While talking about managerial competences in the context of FDI, the interviewees noticed that a different set of skills will be required for a greenfield investment and a different one for a brownfield investment. Greenfield investments require additional knowledge about administrative and legal rules in the foreign country. On the other hand, brownfield investments require the merging and integration skills. Usually, it is the process of merging two companies that determines business success or failure during investment process.

On the one hand, managers need knowledge acquired during university studies or postgraduate education (MBA courses), and on the other hand, they need international experience that is gained over the years. Polish managers have a chance to gain this kind of experience, when working in Polish companies on the processes related to internationalization. However, taking into account the fact that in Poland approximately 30 outgoing direct investments are carried out annually and the free market has been operating for 30 years, it can be concluded that the number of such opportunities for learning and acquiring knowledge is limited. Managers gain knowledge also by working for international corporations operating in Poland, where they can see how effective and proven internal processes of companies are organized, including those related to internationalization. Most often, however, it is the first foreign investment made that is the moment of gaining knowledge and experience. It is worth noting that in order to be considered competent in this topic, a manager must carry out at least a few such processes, often learning from mistakes made. One of the respondents additionally noted that Polish managers have a lot of experience gained in the markets of Eastern Europe, but they are doing worse on the markets of Western Europe.

Meanwhile, Polish enterprises are intensifying their international activities. The willingness to invest is increasing and the demand for managers who will be able to manage foreign investments is increasing. Training and learning managers are a process that takes longer than the development of a given business. Demand exceeds supply. In this context, the question arises what can be done to accelerate the process of accumulation of knowledge and experience and to develop the competences of the managerial staff. One of the respondents mentioned that, in his opinion, Polish curricula (e.g., during MBA studies) lack examples, 
discussing case studies of Polish enterprises that have implemented investments outside Poland. The respondent stated that Poland lacked a system and opportunities to exchange business experiences, especially those that ended in failure. Information on FDIs made by Polish companies is usually provided mainly as press release informing about the successes of Polish organizations. Respondents indicated that it would be a good idea to create a platform for meetings and exchange of experiences. The question arises how to encourage entrepreneurs and managers to share this knowledge without disclosing the company's confidential information such us trade partners, financial situation or strategy. The best source of knowledge are companies and managers who have already participated in the processes of acquisitions of foreign companies or in the construction of plants outside Poland. They are the ones who know how the processes are going, and they are also aware of the most common mistakes. According to the respondents the organization of congresses or thematic discussion panels alone will not allow for deepening the knowledge in this field. One of ideas suggested was to organize an academy of foreign expansion, which could be coordinated by business support institutions. Closing the gap is a crucial challenge both for companies and the economy.

\section{CONCLUSION}

Despite the high dynamics of changes, Poland is still a recipient of foreign capital, as Polish enterprises only carry out about 30 foreign investments per annum. The current crisis related to the Covid-19 pandemic may slow down further internationalization processes and postpone the decision on FDI. The barriers to foreign capital expansion of Polish companies are not only market turbulences, financial constraints or aversion to taking risks, but also the insufficient competencies of the managers. The competencies of the managers, including knowledge, experience and attitudes, have an impact not only on the decision and motivation to undertake FDIs, but also on the long-term success of foreign expansion.

The results of the qualitative research conducted among Polish managers who participated in FDIs projects of Polish companies confirm that there is imbalance between demand and supply for qualified managers. The majority of the respondents believe that it is very important to have international professional experience and familiarity with other cultures, what helps to make contact and communicate in diverse business environment. Respondents find international experience, industry knowledge, openness as well as cultural management skill as the most important managerial competencies in context of internationalization through FDI. What is more, the results show that the Polish companies struggle to find competent managers because the knowledge, skills and experience related to the FDIs are very scarce.

It would be beneficial to set up a platform, where managers could share their knowledge and learn from experience of other companies. This could help to accumulate knowledge and accelerate the forming of international managers.

\section{REFERENCES}

Boermans, M. A., \& Roelfsema, H. (2013). The effects of managerial capabilities on export, FDI and innovation: Evidence from Indian firms. In Asian Business and Management 12, 387408. doi:10.1057/abm.2013.7

Crido. (2020)., M\&A Outlook: Polish cross-border outbound acquisitions 2015-2019, Warsaw.

EY, Attractiveness Survey Europe 2019, Retrieved 15 January 2021, from https://www.ey.com/Publication/vwLUAssets/ey-europe-attractiveness-survey-2019-hrweb/\$File/ey-europe-attractiveness-survey-2019.pdf 
Griffin, R.W. (2007). Podstawy zarządzania organizacjami, PWN.

Johanson, J., \& Wiedersheim-Pau, I.F. (1975). The Internationalization of the Firm: Four Swedish Cases, In Journal of Management Studies 12(3),305-323. doi:10.1111/j.14676486.1975.tb00514.x

Karaszewski, W., Jaworek, M., Kuzel, M., \& Szalucka, M. (2010). Aktywność inwestycyjna polskich przedsiębiorstw za granica w postaci inwestycji bezpośrednich. Raport z badania. Wydział Nauk Ekonomicznych i Zarządzania, Uniwersytet Mikołaja Kopernika w Toruniu.

Krugman, P., Obstfeld, M., \& Meltiz, M. (2012). International Economics. Theory \& Policy. Addison-Wesley.

Latukha, M. O., \& Panibratov, A. Yu. (2015). Management Teams' Competencies for International Operations: Do they Influence a Firm's Result. In Journal of General Management, 40(4),45-69. doi:10.1108/S1745-886220190000014012

NBP, Zagraniczne inwestycje bezpośrednie w Polsce w 2019 roku, Retrieved 15 January 2021, from https://www.nbp.pl/publikacje/zib/zib_2019_n.pdf

OECD, FDI Stocks, Retrieved 15 January 2021, from https://data.oecd.org/fdi/fdistocks.htm\#indicator-chart

OECD (2008). Benchmark Definition of Foreign Direct Investment. Fourth Edition.

Pająk, K. (2003). Kierownik w XXI wieku, Wydawnictwo Elipsa.

Pocztowski, A. (2002). Międzynarodowe zarządzanie zasobami ludzkimi, Oficyna Ekonomiczna.

Polski Instytut Ekonomiczny. (2019). Zagraniczna ekspansja inwestycyjna polskich przedsiębiorstw - tendencje, perspektywy.

UNCTAD, World Investment Report 2020.

Weresa, M.A. (2002). Skutki inwestycji zagranicznych dla gospodarki kraju przyjmującego doświadczenia Polski. - doświadczenia Polski. In Rola inwestycji zagranicznych w gospodarce, Zeszyty BRE Bank-Case, nr 62. 